\title{
Applying for Entitlements: Employers and the Targeted Jobs Tax Credit
}

\author{
John H. Bishop and Suk Kang
}

\begin{abstract}
The Targeted Jobs Tax Credit (TJTC) is probably the most outstanding example of a generous entitlement program with a very low participation rate. Only about 10 percent of eligible youth hired are claimed as a tax credit by their employers. The causes of the low participation rates are analyzed by estimating a Poisson model of the number of TJTC-eligibles hired and certified during 1980, 1981, and 1982. Information costs, both fixed and variable, are found to be key barriers to TJTC participation. The costeffectiveness of TJTC is low because of the stigma attached and the very high recruitment costs of hiring additional TJTC-eligibles. Because employers find it relatively cheap to certify after the fact eligible new employees who would have been hired anyway, this passive mode of participating in TJTC predominates.
\end{abstract}

Policy analysts are most influential when they become involved early in the policy planning process-before a program begins and before special interest groups have sprung up around it. At this stage the analyst is not evaluating existing policies or programs but rather predicting the consequences of hypothetical situations. The role of prospective analysis is especially critical for tax credit and entitlement schemes that are designed to change behavior. The effects of a policy are always hard to predict, but with entitlements it is even difficult to predict costs. Furthermore, the effects of an entitlement are not revealed by putting it into operation. When everyone in a particular group is eligible for a subsidy or tax credit, problems of selection bias increase the difficulty of making valid impact evaluations. Prospective policy analysis requires two things: a theory (or a simplified representation of the key behavioral relationships), and knowledge of the magnitude of key behavioral parameters. A common approach is to estimate the relevant price and income elasticities, and then calculate the effects of the prices and income produced by the subsidy [Hall and Jorgenson, 1967; Bishop and Lerman, 1977; Hammermesh, 1978; Hammermesh and Grant, 1979]. What generally goes unrecognized (at least formally) in these exercises is that costs of administering, learning about, applying for, and responding to these grants and subsidy payments are quite significant and that these costs have major effects on the scale and impact of the program. Behavioral parameters estimated from observed responses to wage-rate differentials cannot, for instance, be applied willy-nilly to simulate the effect of a tax credit for expanding employment, such as the New Jobs Tax Credit of 1977/78.

A common finding of policy simulation studies is that elasticities of response to a subsidy or tax credit are greatest when the object of subsidy is narrowly defined. Even 
though costs decline proportionately with the size of the target, the relevant elasticities of substitution typically rise as the target is more narrowly defined. Often, the resulting policy recommendation is to target the scheme as narrowly as possible [Bassi, 1986]. This ignores the fact that many of the costs of administering and participating in a subsidy or grant program are fixed. They do not vary appreciably with the size of the individual grant or tax credit, and they vary less than proportionately with the number of participants in the program. If a program is too small and too targeted, the costs of learning about it may be larger than the expected benefits of participation. Few targeted individuals and firms will participate, and the administrative costs may outweigh the social benefits.

Another danger of targeting is that members of the target group may be stigmatized. Target group members who were in the past incognito may now be publicly identified. When told that government is offering to subsidize the hiring of person $\mathrm{A}$, employers may become suspicious of person A's competence or reliability [Bishop, $1989]$.

The theory and empirical analysis that inform prospective policy analysis cannot, then, be limited to the standard income and substitution parameters of production and utility theory. An understanding of the administrative and information costs involved in running and participating in the program must also be included. Policy analysts need a body of literature on these issues: one that explains what happened five years ago when program $X$ was implemented, and that can aid in predicting the information costs and participation response to subsidy schemes that are under consideration.

This paper examines the Targeted Jobs Tax Credit (TJTC), perhaps the most outstanding example of an entitlement program with extremely low participation rates despite a very generous subsidy offer. Between 1979 and 1985, firms that hired certain disadvantaged individuals were eligible for a tax credit equal to one-half of the first $\$ 6000$ of wages paid in the first year of employment and one-fourth of such wages in the second year. The eligible target groups were handicapped individuals, welfare recipients and economically disadvantaged youth, Vietnam veterans, and ex-offenders. Between 1981 and 1985, the number of targeted individuals who were hired and determined to be eligible (certified) ranged between 200,000 and 586,000 annually. Large as these numbers may seem, they represent only a small fraction of the total number of eligible individuals hired during this period. The Congressional Budget Office has estimated that TJTC helped less than 10 percent of the eligible young people who were hired during 1983 [Christensen, 1984]. Furthermore, the companies that participated in TJTC in 1982 accounted for only about 4 percent of the nation's employers and less than 20 percent of the nation's jobs. In a 1982 survey, 73 percent of the employers who had some familiarity with the program said they did not plan to ask for TJTC-eligible referrals when they needed unskilled workers in the future.

Low take-up rates for targeted hiring subsidies are not a uniquely American phenomenon; European efforts to subsidize the employment of particular target groups have also had low participation rates [Schmid, 1981]. Similarly low take-up rates have occurred for other tax subsidies. For example, the 1954 income tax code revision allowed firms to use accelerated depreciation schedules on all new investment, but six years later only 21 percent of all proprietorships and 30 percent of all corporations were using an accelerated depreciation method on any component of their capital stock [Ture, 1967]. 
What happened with TJTC? Why did employers turn such a cold shoulder on such a generous subsidy? Clearly, the expected costs of learning about and participating in this program must, for most firms, have been larger than the expected benefits. What are these costs? Has TJTC's highly targeted nature, as Bishop and Haveman [1979] suggested, stigmatized the workers it was designed to help? What implications do high nonpecuniary costs of participation and the resulting low participation rates have for the policy analysis of programs, like TJTC, that subsidize activities considered to be in the public interest-such as hiring the disadvantaged, or increasing $\mathrm{R} \& \mathrm{D}$ spending? These are the questions this paper addresses.

The first section that follows develops a very simple Poisson representation of employer participation in TJTC. The extent of participation is analyzed as it relates to the expected tax benefits as weighed against the fixed and variable costs of learning about and participating in the program. This model generates a number of predictions about which employers will be the heaviest users of TJTC and how these patterns will change over time. The next sections present the results of data analysis from a large-scale employer survey on the use of TJTC, and examine whether most of the employers participating in the program are active users who try to increase their hiring of eligibles, or passive users who seek tax credits for people they would have hired even without the program. The paper then explores how the stigma issue relates to the use and the effects of the program. A summary section recounts the empirical findings, discusses some options for reforming TJTC, and draws some conclusions about how prospective policy analysis should proceed in the future.

\section{MODEL SPECIFICATION}

Bishop [1982], Ashenfelter [1983], and Moffitt [1983] have shown that the low participation rates in many income maintenance programs can be explained by models in which participation stigmatizes the individual or entails other significant nonpecuniary costs. On the surface it might appear that decisions to participate in the Targeted Jobs Tax Credit are very different from decisions to participate in income tested transfer programs. Since employers make the participation decisions, factor demand theory rather than utility theory is relevant. In TJTC, the person who decides whether to participate and who receives the subsidy is not stigmatized by participation; rather the stigma falls on the eligible job applicants. The potential tax credit is very much larger than the payment a poor family can receive from welfare, so incentives to learn about the program would appear to be stronger. Nevertheless, nonpecuniary costs of participation are the primary reason for low participation rates. While such costs arise for different reasons, their structure is rather similar to that assumed by Moffitt's [1983] analysis of welfare participation. In both cases, nonpecuniary costs depend on both the fact and the extent of participation; and in both cases, a change in the decision maker's behavior can increase the subsidy received. As a result, the costs of TJTC participation affect employer behavior-lowering participation rates and reducing incentive effects - in much the same way that stigma affected individual behavior in Moffitt's analysis of welfare. We will return to these similarities in a later section.

The nonpecuniary costs of participating in TJTC derive largely from the fact that it subsidizes the hiring of workers who are both hard to identify and generally thought to 


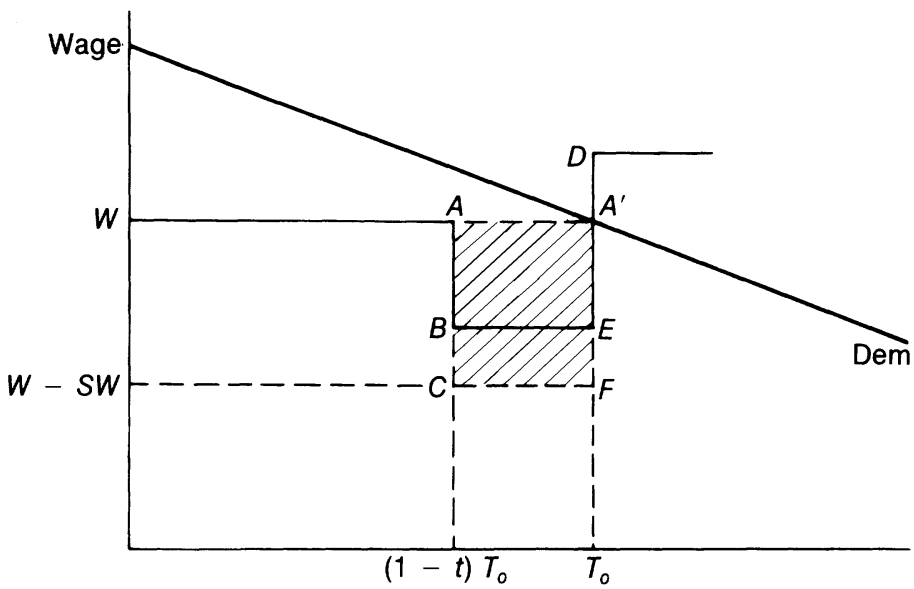

Figure 1. Costs and benefits for the passive participant in TJTC. 
be below average in productivity. Because the targeting criteria involve family income and receipt of welfare, the government must come in to certify whether each individual is eligible. Even if the firm has already hired people who are TJTC-eligible, participation has its costs: The employer must learn about the program, establish a relationship with the administering agency, and apply for certification of those new hires thought to be eligible. Since September 1981, employers have been required to apply for certification prior to the new hire's first day of work. The costs of passive participation-obtaining tax credits without changing the number of eligibles hired-are both fixed $\left(C_{p}\right)$ and variable $\left(c_{p}\right.$ per eligible certified). Assuming homothetic technology and no TJTC-induced change in the rate of turn-over of targeted labor $(t)$, in the exogenous growth rate of the establishment $\left(g_{o}\right)$, and in who is hired, passive participation is preferable to nonparticipation if:

$$
\text { Net Benefits } s_{p}=N B_{p}=\left(S W-c_{p}\right)\left(g_{o}+t\right) T_{o}-C_{p}>O
$$

where $S$ is the rate of subsidy ( 0 if the firm has no tax liability), $W$ is the wage of target group labor and $T_{o}$ is the number of eligible workers employed in the base period. The case of the passive user of the TJTC program with stable employment $\left(g_{o}=0\right)$ is illustrated by Figure 1. The subsidy payment made to the company is the crosshatched area, and the variable cost of obtaining tax credits is the area $B C F E$. The net benefits of passive participation are shown by the area $A A^{\prime} E B$ minus $C_{p}$.

The objectives of TJTC are realized only if firms are actively responding to the subsidy incentive by increasing their hiring of targeted workers. At first glance, it might seem always advantageous for a participating firm to increase hiring of eligibles. This is not necessarily the case, however, because active participation is more costly than passive participation, and these additional costs may outweigh the additional tax credits that can be obtained by purposely expanding the hiring of eligibles. Many employers believe that TJTC-eligibles are less productive than other job applicants [Bishop and Hollenbeck, 1986]. Prior to TJTC, asking job applicants whether they were welfare recipients or disadvantaged was generally thought to be illegal, so people from stigmatized groups typically obtained jobs without the employer learning of their disadvantaged status. Even with the help of TJTC, many disadvantaged job seekers believe, probably correctly, that revealing their disadvantaged status will reduce their chances of being hired [Burtless, 1985; Moran et al., 1982]. If only a minority of eligibles are aware of their eligibility or willing to reveal it, finding additional TJTC-eligibles who come close to meeting the firm's hiring criteria becomes very expensive. Thus, trying to hire additional TJTCeligibles may generate delays in filling openings and result in a higher proportion of the new hires performing poorly on the job. These variable costs of active participation are assumed to be a constant amount (ca) per additional eligible hired. In Figures 1 and 2 the magnitude of the variable costs of active participation is indicated by line segment DE. In Figure 1 these costs are so high, the firm chooses not to reorient its hiring practices so as to increase the number of eligibles hired. In Figure 2 the variable costs of active participation are lower, so the firm responds to the subsidy program by increasing the hiring of eligibles.

The additional costs of active participation are also to some degree fixed $\left(C_{a}\right)$, because an increase in the hiring of eligibles necessitates a shift of recruitment efforts to 


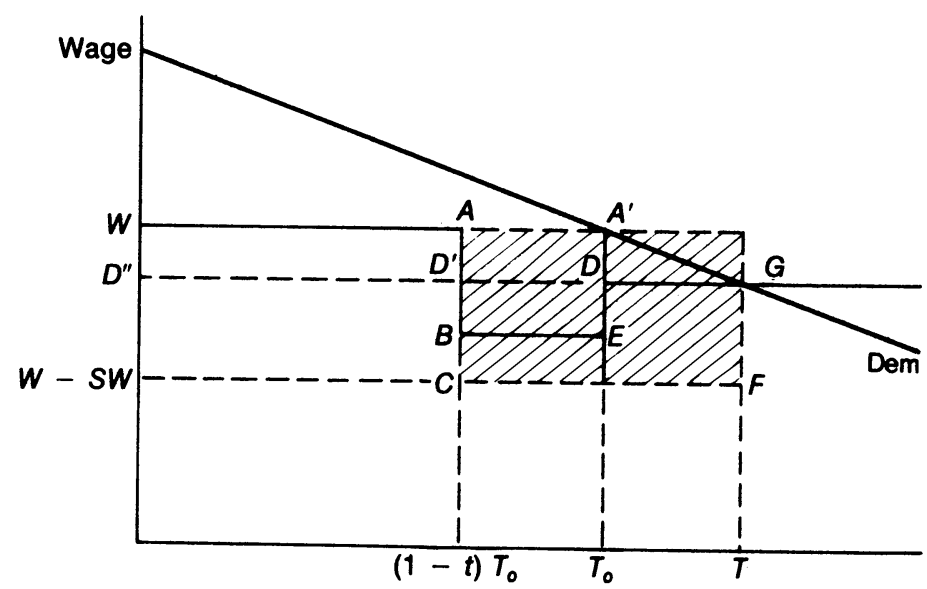

Figure 2. Costs and benefits for the aggressive participant in TJTC. 
labor market intermediaries that can refer eligibles and/or the development of a mechanism for screening all job applicants (not just those hired, as in passive participation) for eligibility. For firms that are active participants in TJTC, the growth of eligible employees at the firm becomes endogenous. Whether a firm will choose active participation over nonparticipation can be judged by comparing the profits obtainable at the effective post-subsidy wage of $(1-S) W+c_{p}+c_{\mathrm{a}}$ (after subtracting participation costs and the subsidy on the previously employed workers) to the profits obtainable if the firm does not participate [Ashenfelter, 1978; Montgomery, 1982]. ${ }^{1}$ Letting $\pi$ be the profit function and $P$ be the vector of all other prices, the net benefits to active participation, $N B_{a}$, can be expressed as:

$$
\begin{array}{r}
N B a=\pi\left(P,(I-S) W+c_{p}+c_{a}\right)-\pi(P, W)-C_{p}-C_{a} \\
-\quad\left(S W-c_{p}-c_{a}\right)(l-t) T_{o}+c_{a}\left(t+g_{o}\right) T_{o}
\end{array}
$$

The second term gives the firm's profit, assuming no effort is made to claim a TJTC tax credit. The first term of the equation is the profit function evaluated for a wage, $(1-S) W$ $+c_{p}+c_{a}$ ), that is net of both subsidy benefits and variable participation costs. Since the subsidy is for recruitment of new employees, no subsidy is received for eligibles hired in the past, $(1-t) \mathrm{T}_{\mathrm{o}}$. The fifth term makes the subtraction necessary to account for this fact and gives the area in Figure 2 of $W A D^{\prime} D^{\prime \prime}$. The final term of equation (2) is the mathematical expression for the area $D^{\prime} D E B$, the marginal cost of active participation times the number of eligible new hires that would have been claimed if the subsidy had not induced any increase in the hiring of eligibles.

The firm participates if either (1) or (2) is positive. If (1) is larger than (2), the number of targeted workers certified is $\left(t+g_{0}\right) T_{o}$ and the employer does not increase the hiring of eligibles and is thus termed a passive participant. This case is illustrated by Figure 1, where $c_{p}=$ line segment $B C$ and $c_{a}=$ line segment DE. Otherwise, the number of targeted workers certified comes from maximizing (2), and the employer increases hiring of eligibles and is thus termed an active participant. This case is illustrated by Figure 2 .

\section{Hypotheses to be Tested}

The theory just sketched suggests a number of testable hypotheses about which firms are most likely to participate in TJTC. Obviously a firm is more likely to be a heavy user of the program if it has many job openings for unskilled workers. Consequently, the following indicators of the potential scale of hiring of unskilled workers by the sampled establishment are hypothesized to have positive effects on TJTC use:

- Total employment at the establishment times the proportion of the work force in low-skill occupations $\left(T_{o}\right)$.

\footnotetext{
${ }^{1}$ Note that it has been implicitly assumed that the firm is constrained from firing all of the low-skill workers currently employed and replacing them with subsidized new hires. Most firms are at least partly constrained from simply firing workers without apparent cause. This assumption is reasonable because the training costs for new workers often exceed the magnitude of the subsidy, and because there have been as yet no documented cases of experienced workers being fired to hire a subsidy-eligible worker.
} 
- The growth rate of employment at that establishment $\left(g_{o}\right)$.

- The rate of turnover of unskilled workers $(t)$.

- The elasticity of demand for unskilled labor.

Firms that have shown a willingness to hire and train unskilled workers in the past face lower incremental costs of active participation $\left(c_{a}\right)$ than other firms. This increases the probability and amount of participation, so the following characteristics are hypothesized to raise the likelihood of participation:

- Being a nomunion firm with flexibility in terminating unwanted workers. Employers feel that hiring a subsidized worker increases the risk that things will not work out. If the firm can easily correct a hiring mistake by firing the worker, the costs of mistakes are reduced.

- Having on-the-job training (OJT) that is general rather than specific. The turnover rates of TJTC eligibles are believed to be higher than for other competing workers. If OJT is extensive and specific to the firm, these higher rates of turnover will impose significant costs on the firm and raise the marginal cost of participation. If training is general and workers pay for the training, higher turnover rates will not be a serious problem.

- Having below-average starting wage rates. The marginal costs of participation will be lower because the firm will already be accustomed to providing the additional training that TJTC eligibles might require.

- Having been contacted by Employment Service officials offering to refer TJTC-eligibles.

- Having used the Employment Service in the past.

Only one indicator of the incremental costs of passive participation $\left(c_{p}\right)$ is in the data set:

- Having a high proportion of workers who are full-time. Marginal participation costs are the same for each worker, regardless of the numbers of hours worked. The subsidy is typically larger for full-time workers. Consequently, the difference between subsidy and marginal participation costs is greater for full-time workers, and incentives are stronger both to apply for certifications (passive participation) and to recruit additional eligibles (active participation).

Since lower fixed costs of participation $\left(C_{p}\right.$ and $\left.C_{a}\right)$ raise the probability of participation, the following types of employers are hypothesized to be more likely to participate in TJTC:

- Establishments that are part of a large multi-establishment firm. Such firms spread the fixed costs of learning how to use the program and revising internal administrative procedures over many establishments. All other scale variables refer to the establishment, not the firm.

- Establishments that have personnel directors. Personnel directors have more time to learn about programs like TJTC than owners or plant managers, 
and they are also more likely to be targeted for outreach by agencies seeking to place TJTC-eligibles.

- Members of local business organizations. These employers are more likely to get a "sales pitch" about TJTC at meetings or in a newsletter.

- Employers contacted by local program administrators.

- Employers that have participated in this or similar programs in the past. Participation in one program teaches the firm how to handle the paperwork and generates contacts that facilitate future use of TJTC. A firm's experience with eligible workers may also result in more favorable attitudes towards them. A variable for past participation may also pick up the effects of unobserved heterogeneity.

- Employers with a positive attitude toward government.

- Regular users of the employment service.

Participation is defined as the number of target group members hired and certified. In the sample of establishments studied, about 90 percent did not hire and certify any TJTC worker, 5 percent hired and certified 1 to 5 workers, and the remaining 5 percent hired and certified more than 6 workers. Because of the highly skewed and discrete nature of the distribution, the Poisson specification proposed by Hausman, Hall, and Griliches [1984] is employed. The model is specified in terms of the establishment's probability of hiring and certifying zero, one, two, .. . TJTC workers. The Poisson distribution gives the probability of nonnegative integer outcomes. The probability function is given by the following formula:

$$
\begin{aligned}
\operatorname{Pr}(N i)=\exp (-m i) & m_{i} N_{i} N_{i} !(m,>O, N i=0,1,2 \ldots) \\
& \text { where }(m i>0, N=0,1,2 \ldots)
\end{aligned}
$$

For instance, the probabilities of hiring zero, one, and two TJTC workers are given by:

$$
\begin{aligned}
& \operatorname{Pr}(0)=\exp \left(-m_{i}\right) \\
& \operatorname{Pr}(1)=\exp \left(-m_{i}\right) m i \\
& \operatorname{Pr}(2)=\exp \left(-m_{i}\right) m_{i}^{2} / 2
\end{aligned}
$$

The parameter $m_{\mathrm{i}}$ is assumed to be specific to the $i$ th employer and is determined by the employer's characteristics. Specifically it is assumed that $m_{i}$ is determined by the following formula:

$$
\log m_{i}=X_{i} B
$$

$X_{i}$ is a vector of the variables representing the $i$ th employer's characteristics and $B$ is a vector of coefficients. One of the very attractive features of the Poisson specification is that the partial derivative of $\mathrm{m}_{i}$ with respect to the $j$ th explanatory variable, $X_{i j}$, is

$$
\partial m_{i} / \partial_{i j}=\partial E\left(N_{i}\right) / \partial X_{i j}=b_{j} \exp \left(X_{i} B\right)=b_{j} E\left(N_{i}\right)
$$


where $\mathrm{E}$ is the expectation operator and $E\left(N_{i}\right)$ is the expected number of TJTC certifications for the $i$ th employer. Consequently, when $X$ variables are $\operatorname{logs}$, the $b_{j}$ coefficients are elasticities of TJTC use. When $X$ variables are categorical or range between zero and one, $b_{j}$ measures the proportionate response of TJTC certification to the $j$ th characteristic. Estimates of $B$ are obtained by maximizing the $\log$ likelihood function which is written as,

$$
L(B)=\sum\left(-\log N_{i} !-\exp \left(X_{i} B\right)+N_{i} X_{i} B\right.
$$

\section{RESULTS}

This section presents the results of a multivariate analysis of the determinants of TJTC use. The database analyzed is a 1982 survey of 3,412 employers, designed by staff at the National Center for Research in Vocational Education and conducted by the Gallup Organization. This survey was a reinterview of respondents to the 1980 Employment Opportunity Pilot Projects employer survey. The original sample was a stratified random sample of establishments (with higher probabilities of selection for large establishments in low wage industries) paying unemployment insurance taxes in 10 pilot sites, and 18 comparison sites selected for their similarity to the pilot sites. A complete description of the sample, the survey, and copies of all relevant questions are available in Bishop [1985] and Bishop and Hollenbeck [1986]. Models were estimated predicting the number of TJTC-eligibles hired and certified in 1980, 1981, and 1982. The definition, means, and standard deviations of the variables used in the models are presented in Appendix Table 1 (which can be obtained from the authors). The explanatory variables have been classified into these categories: indicators of the number of job openings at the establishment that could potentially be filled by eligibles; characteristics of the employer that relate to the fixed and variable costs of obtaining certifications; measures of government effort to encourage firms to hire TJTC workers; and the firms' past experience with governmentsponsored employment subsidy programs. Except for the variables that pertain to the previous experience with TJTC, we do not have yearly observations on the right hand side variables

The model was estimated separately for each of the three years in order to capture how the employer response to the TJTC program changed over time. Changes in employer response to the program are to be anticipated because (1) the program was new in 1979 and many of the employers learned of the program after 1980; (2) response to the program evolves over time as the firm becomes more familiar with the required paperwork and how to recruit and train members of the target groups; (3) the rules of the program changed significantly in 1981; and (4) efforts of local administrators to promote the program changed over time. The estimation results are presented in Table 1.

\section{Indicators of the Number of Job Openings That May Be Filled by Eligibles}

The indicators of the number of unskilled job openings during the year included in the regression are the $\log$ of establishment employment in 1980, the new hire rate in the 
Table 1. Determinants of TJTC hiring. (Number of observations $=2,621$ )

\begin{tabular}{|c|c|c|c|c|c|c|}
\hline Variables & 198 & & 198 & & 19 & \\
\hline adicators of the num & eligib & & & & & \\
\hline $\begin{array}{l}\text { Log estab. empl. } \\
\text { in } 1980\end{array}$ & $0.761^{\mathrm{c}}$ & $(26.9)$ & $.855^{\mathrm{c}}$ & $(31.63)$ & $.462^{\mathrm{c}}$ & $(12.65)$ \\
\hline $\begin{array}{l}\text { New hire rate in } \\
\text { 1979: IV }\end{array}$ & & & 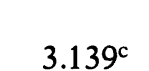 & & 3.606 & \\
\hline $\begin{array}{l}\text { Proportion under } 25 \\
\text { in } 1979\end{array}$ & -1.125 & $(.65)$ & $1.113^{\mathrm{c}}$ & $(6.90)$ & $.702^{\mathrm{c}}$ & (3.48) \\
\hline $\begin{array}{l}\text { Proportion unskilled } \\
\text { in } 1979\end{array}$ & $0.266^{\mathrm{b}}$ & $(2.17)$ & $-1.95^{\mathrm{a}}$ & $(1.70)$ & $1.468^{\mathrm{c}}$ & (9.53) \\
\hline Indicators of incremento & participat & ion cost & & & & \\
\hline $\begin{array}{l}\text { Log index of general } \\
\text { training }\end{array}$ & $.280^{c}$ & $(7.49)$ & $.218^{\mathrm{c}}$ & $(6.12)$ & $-.106^{\mathrm{b}}$ & $(2.04)$ \\
\hline of specific & $.130^{\mathrm{a}}$ & $(1.79)$ & $.318^{\mathrm{c}}$ & & & 0) \\
\hline Unio & $-.271^{\mathrm{b}}$ & $(2$. & $.409^{\mathrm{c}}$ & & $-1.040^{\mathrm{c}}$ & $(c$ \\
\hline Pr & -.237 & $(1.28)$ & $-.284^{\mathrm{a}}$ & ) & .193 & $(1$ \\
\hline og & $-.075^{c}$ & $(3.86)$ & $-.103^{c}$ & $(5$. & $.157^{\mathrm{c}}$ & $(6$ \\
\hline Wag & $-.347^{c}$ & $(3.5$ & .051 & $($. & .162 & $(1$. \\
\hline $\mathrm{d}$ in 1979 & $.144^{\mathrm{a}}$ & $(1.83$ & $.233^{\mathrm{c}}$ & $(3.09)$ & $-.557^{\mathrm{c}}$ & $(5.60)$ \\
\hline $\begin{array}{l}\text { Layoff based on } \\
\text { seniority } \\
\text { Indicators of fixed cost }\end{array}$ & .111 & $(.98)$ & $-.191^{\mathrm{a}}$ & $(1.80)$ & $.322^{\mathrm{b}}$ & $(2.23)$ \\
\hline $\begin{array}{l}\text { Log firm/ } \\
\text { employ }\end{array}$ & -.071 & $(2.0$ & $.083^{\mathrm{c}}$ & & $364^{c}$ & \\
\hline nnel office & -.120 & $(1.43$ & $.201^{\mathrm{a}}$ & (2.50) & $.263^{c}$ & $(2.29)$ \\
\hline $\begin{array}{l}\text { Member } \\
\text { local b } \\
\text { organi }\end{array}$ & $.310^{c}$ & $(4.17)$ & .006 & $(.08)$ & .146 & $(1.65)$ \\
\hline $\begin{array}{l}\text { Listed opening with } \\
\text { employment service } \\
\text { in } 1979\end{array}$ & $-.503^{c}$ & $(6.92)$ & $-.167^{b}$ & (2.49) & 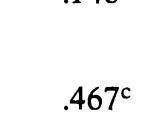 & $(4.78)$ \\
\hline Outreach & & & & & & \\
\hline $\begin{array}{l}\text { Govern } \\
\text { eligib } \\
\text { Conver: }\end{array}$ & $2.467^{\mathrm{c}}$ & (20.9) & $1.58^{\mathrm{c}}$ & (18.25) & $2.204^{\mathrm{c}}$ & $(17.83)$ \\
\hline $\begin{array}{l}\text { TJTC not } \\
\text { by firm }\end{array}$ & $.626^{c}$ & $(3.74)$ & $.358^{\mathrm{c}}$ & (3.00) & $.563^{\mathrm{c}}$ & (3.06) \\
\hline $\begin{array}{l}\text { Both a conversation } \\
\text { and a referral offer } \\
\text { Previous receipt of subst }\end{array}$ & dies $^{-.937^{c}}$ & $(5.18)$ & $-1.019^{c}$ & (7.40) & $-1.222^{c}$ & $(5.82)$ \\
\hline $\begin{array}{l}\text { New jobs tax credit } \\
\text { WIN in } 1977.78\end{array}$ & $.376^{\mathrm{c}}$ & $(4.31)$ & $.250^{c}$ & $(2.97)$ & $.928^{\mathrm{c}}$ & $(8.62)$ \\
\hline or & .12 & & 0 & & .2 & \\
\hline CETA-OJT in 78 or 79 & $.614^{\mathrm{c}}$ & $(6.23)$ & $.891^{\mathrm{c}}$ & $(10.85)$ & $1.092^{\mathrm{c}}$ & $(9.06)$ \\
\hline
\end{tabular}

$t$-value in parenthesis

a Significant at the $10 \%$ level (two sided)

${ }^{b}$ Significant at the 5\% level (two sided)

c Significant at the $1 \%$ level (two sided) 
fourth quarter of 1979, the proportion of the workers under age 25 in 1979, and the proportion of unskilled workers in 1979. The 1979 values of these variables are used because later values have been found to be influenced by the extent of participation in the program [Bishop and Montgomery, 1987], and their inclusion in the model would probably cause simultaneous equations bias.

Since the $\log$ of the ratio of firm and establishment employment is also included in the model, the pure effect of establishment size is the coefficient for establishment size minus the coefficient for log of the ratio of firm size to establishment size. The difference gives the elasticity of the number of certified workers with respect to establishment size while holding firm size constant. The elasticity estimates are 0.83 and 0.78 in 1980 and 1981, but the estimate dropped to 0.10 in 1982. This drop in the effect of establishment size may have been a response to the recession and the changes in program rules - the end of eligibility for cooperative education students, and the requirement that applications for certification be made prior to the new hire's starting work-that occurred at the end of 1981.

The new-hire rate in the fourth quarter of 1979 had a large positive effect on TJTC use, as hypothesized. A one percentage point increase in the new hire rate was associated with a 1 percent increase in TJTC employment in 1980 and a more than 3 percent increase in 1981 and 1982. The share of employees that were under age 25 in 1979 had the hypothesized large positive effects on use of TJTC in 1981 and 1982 but inexplicably not in 1980. The proportion of the firm's jobs that were unskilled (i.e., in laborer, operative, or service occupations) also had the hypothesized positive effect on TJTC use in 1980 and 1982 but not in 1981.

\section{Indicators of the Incremental Cost of Active Participation}

The indicators of the low skill, low wages, and lack of job security that were hypothesized to be associated with low incremental costs of active participation and therefore with heavy use of TJTC did have the expected effects in 1980 and early 1981. The characteristics that appear to have in-creased TJTC use were

- offering new employees more than the usual amount of general training,

- offering new employees less than the usual amount of specific training,

- having low capital investment per worker,

- having lower than average wage rates, and

- having fired someone in the fourth quarter of 1979 .

After September 1981, however, the pattern changed and the firm characteristics that appear to have resulted in heavier use of TJTC were

- being nonunion,

- having high capital investments per employee, and

- not having fired someone in the fourth quarter of 1979. 
The results for the post-ERTA period support our hypotheses about unionization but contradict our hypotheses regarding the effect of the other indicators of participation costs. One can only speculate as to why indicators of incremental participation costs that had the predicted effects on utilization in 1980 and 1981 should no longer have such effects after the ERTA amendments went into effect. The ERTA amendments made two major changes in TJTC: The blanket eligibility of cooperative education students was ended, and retroactive certifications were abolished. The first change might very well have reduced the training content of the typical TJTC-subsidized job. Since cooperative education placements can be thought of as low-skilled workers being placed in and trained for medium-skilled jobs, another consequence of the decrease in the number of the cooperative education students getting TJTC certifications might have been a shift toward firms with predominantly unskilled jobs. This might explain the big increase between 1981 and 1982 in the response of TJTC hiring to the proportion of the firm's jobs that are unskilled. The 1982 recession might also be responsible.

\section{Indicators of Fixed Cost}

The results also provide support for the hypothesis that fixed costs are an important determinant of TJTC use and that the pattern of fixed costs has substantially changed. Being a member of a local business organization had a big effect on participation in 1980 but not in later years. Having a personnel office did not increase program use at first, but it became important in 1981 and 1982. Probably the most dramatic change has been the growth in the use of TJTC by multi-establishment firms. In 1981, establishments that were part of a chain were less likely to use TJTC. This changed in 1981, and in 1982 the ratio of firm to establishment employment had become one of the most important determinants of TJTC use. We asked managers of 35 multiestablishment firms about this in a survey conducted during 1985 [Hollenbeck, 1985]. They reported that local managers had at first been unaware of the program and reluctant to get involved in TJTC because the tax benefits did not get passed through to their establishment's profit and loss statement. In 1981 the corporate staff of many of these companies started to encourage their local managers to use TJTC and promoted its use by offering incentives to local managers for hiring TJTC-eligibles. Multi-establishment firms now account for most TJTC certifications. The size of the establishment is no longer a primary determinant of TJTC usage; instead, the primary determinants seem to now be turnover rate, proportion of unskilled or young workers, and the size of the firm (rather than the establishment).

The impact of being a user of the employment service during 1979 on later use of TJTC changed dramatically between 1980 and 1982 as a result of the ERTA amendments. Government contacts about TJTC and offers of eligible referrals are positively associated with having listed job openings in 1979. Holding referral offers constant, listing with the employment service apparently reduced use of TJTC in 1980 but increased it in 1982. This change is no doubt due to the abolition of retroactive certification and the resulting greater use of employment service referrals to identify TJTC-eligibles before hiring. Prior to September 1981, 18 percent of the TJTC workers known to be eligible when hired were recruited through the employment service. In the 
six months following that date, 28.5 percent were recruited through the employment service.

\section{Outreach}

Government outreach efforts which lower the costs of participation, should have major effects on TJTC use. The analysis of the first wave of the employer survey found that firms learning of the Welfare Work Incentive (WIN) program through personal contact by a representative of a government agency or local business organization were 84 percent more likely to participate in WIN during 1979, and 63 percent more likely to participate in TJTC, than firms that had first heard about the program from other sources [Bishop and Montgomery, 1986]. Having first heard of Comprehensive Employment and Training Act on-the-job training (CETA-OJT) from a personal contact more than doubled the chances of participating in CETA-OJT during 1979

In the second wave of the survey, employers who had heard of TJTC were asked two questions about government-initiated contacts promoting the TJTC program. The first question was: "Have you or any of your staff spoken to a representative of government, a trade association, or a local business organization about these tax credits?" If so, they were asked who initiated the contact. Thirteen percent responded that a governmental official had initiated a conversation with them about TJTC. The second question was, "Have you been asked by the employment service or any other agencies to accept referrals of job applicants who are eligible for Targeted Job Tax Credits or Work Incentive tax credits?" Twenty-one percent responded that they had received such a request. Approximately 10 percent reported both types of interactions

The coefficients reported in Table 1 measure the expected proportionate increase in certification of TJTC-eligibles induced by each type of government-initiated contact. Contacts with an employer that include an offer to refer TJTC-eligible job candidates to the firm had a much larger impact on TJTC certifications than conversations that promoted the program but did not offer a referral. The coefficient on the indicator variable indicating that the government offered to refer an eligible is 2.467 . This implies that making such an offer increases the expected number of TJTC certifications at that establishment by a factor of 12 . In the next two years the coefficients are positive and highly significant; the point estimates in 1981 and 1982 are 1.58 and 2.201, respectively.

\section{Previous Receipt of Other Subsidies}

As hypothesized, participation in similar subsidy programs prior to 1980 had a large statistically significant impact on TJTC certifications. The effects of participation prior to 1979 did not diminish with time; they were even larger in 1982 than they were in 1980. Firms that participated in all three of the programs prior to 1980 certified ten times as many TJTC eligibles as firms that had participated in none. These effects are partly a result of learning and partly a consequence of unobserved differences across firms in their propensity to participate in subsidy programs. 


\section{EVIDENCE OF THE EXTENT OF ACTIVE PARTICIPATION}

We now turn to the effects of nonpecuniary participation costs on the effectiveness of the program. As Moffitt [1983] points out, the effects of participation costs on the labor supply of welfare recipients-or, in this case, the hiring of disadvantaged workers by firms-depends on whether these costs are primarily fixed or variable. From the perspective of the Moffitt model, what have been called fixed costs of active participation $\left(C_{a}\right)$ are really variable costs that experience a discrete jump when the firm chooses consciously to increase its hiring of eligibles. The fixed costs of passive participation (e.g., the costs of learning enough about the program to use it, establishing a system to identify which new hires are eligible, and risking greater scrutiny from the Equal Employment Opportunity Commission or the Internal Revenue Service) discourage participation; but for those who do participate, such costs should have no systematic effect on the impact of the subsidy on employment. Consequently, cost-effectiveness is not diminished. Employer characteristics associated with low fixed costs-membership in business organizations, a personnel officer, and previous use of the program-had great effects on participation. But these variables could be proxying for the fixed and variable costs of active participation as well, so this fact should not be interpreted as favorable news about cost-effectiveness.

The variable costs of participation are the costs of making arrangements for the referral of eligible workers and of identifying and certifying eligible workers, and the risk of hiring workers who are less productive than the typical unsubsidized new hire. These costs lower the net benefit of hiring additional subsidized workers and, therefore, increase the chances the firm will only passively participate in the program or reduce its response when it is an active participant. Since some windfall payments are inevitable, any-thing that reduces the behavioral response tends to reduce cost-effectiveness as well. The foregoing analysis provides evidence that the incremental costs of participation are quite high for many firms. Various indicators of these costs-training costs, unionization, the cost of machinery and willingness to fire, past use of the employment service, and contacts by the employment service offering to refer eligibles - had significant effects on participation.

This evidence that the costs of active participation are high suggests that the predominant form of participation in TJTC may be passive. However, the evidence is by no means definitive. Better evidence on the issue comes from studying the administrative mechanisms that firms have established to participate in TJTC. The mechanism that now produces the great majority of certifications is as follows: Employers who believe that some of their new hires are eligible send a letter td the employment service requesting certification for each new hire. This letter must be sent before the new hire begins work, but the determination of the worker's eligibility by the employment service may occur many weeks later. Sometimes employers make such requests for every-one they hire. In most cases, however, the new hires are screened for eligibility by the employer or over the phone by an outside contractor. This screening generally occurs after the hiring decision is made. The evidence that screening comes after hiring comes from two surveys. During the summer of 1985, staff of the National Center for Research in Vocational Education interviewed corporate, regional, and local managers of 35 large multi-establishment firms in industries that are heavy users of TJTC, accounting for 
about 15 percent of all TJTC certifications. Those interviews revealed that screening takes place after the hiring decision in 5 of the 8 fast food chains, 5 of the 7 hotel chains, and 17 of the 20 other firms studied [Hollenbeck, 1985].

In many states, consulting firms handle the screening and certification paperwork for more than half of the TJTC certifications. During March 1986 a second series of telephone interviews was conducted with 13 outside con-tractors that did TJTC screening and paperwork for the original sample of 35 firms. Ten of these contractors reported that more than 95 percent of their clients screen for TJTC eligibility after rather than before the hiring decision. One consulting firm thought a significant number of its clients were prescreening, but could not estimate how many. Another routinely encouraged its clients to screen prior to making selections and thought that three-quarters were doing so. The third firm had developed a proprietary screening procedure that was apparently administered by the firm prior to the hiring decision. Most of these consulting firms are apparently marketing systems that greatly simplify passive participation but fail to stimulate the active forms of participation sought by the program designers.

The final bit of evidence on the issue comes from the 1982 survey. Employers who knew or thought they were hiring TJTC-eligibles were asked directly, "How much did this possibility of eligibility increase the applicants chances of being hired?" Only 18 percent reported they were influenced "a great amount" and only 15 percent reported being influenced a moderate amount. "Not very" was selected by 23 percent, and "not at all" by 46 percent. In summary, the evidence clearly indicates that the predominant mode of participation in TJTC is passive, and therefore that the windfall element of the program is probably quite large.

\section{THE STIGMA PROBLEM}

One of the most important determinants of TJTC use is employer beliefs about the productivity of individuals who are eligible for subsidy. The survey asked all employers who had heard of TJTC if they thought "that tax-credit-eligible people usually make better or poorer new employees than people who are not tax-credit eligible." Despite the fact that the socially acceptable response is clearly "don't know," "no difference," or "better," 28 percent of our respondents admitted to believing that TJTC-eligibles were poorer workers than average; only 7 percent said they made better workers. A stigma index was constructed, assigning +1 for employers who thought eligibles made betterthan-average workers, 0 for those who thought it made no difference, and -1 for those who thought eligibles made poorer workers. For nonparticipating firms that answered the question, the un-weighted mean of this stigma index was $-.46{ }^{2}$ The views of participating employers were less negative. Their unweighted mean on the stigma index was -.17 . Weighting the participants by the number of subsidized hires significantly

\footnotetext{
${ }^{2}$ Employers who had not participated in the program typically did not know which of their current employees are eligible for TJTC, and may not even have known what makes a person eligible. Their opinions may reflect prejudice more often than actual experience. Although the employers who participated in the program typically had a chance to observe directly how well particular TJTC-eligible employees did, subjective productivity measures are not very reliable, so their opinion is probably some mixture of previous prejudices and recent experiences.
} 
raised the average opinion of TJTC-eligibles. When weighted by usage of TJTC, the mean of the stigma index was roughly zero (-.05 and .04, depending on whether beforeERTA or after-ERTA use of TJTC serves as the weighting factor). There is a strong negative correlation between stigmatizing beliefs about eligibles and employer use of TJTC. No doubt these beliefs influence participation. But does participation also influence these beliefs? Let us now turn to this question.

\section{Is TJTC Reducing Stigma?}

Since most employers do not know when they have hired someone on welfare or from a disadvantaged background, they have no empirical basis on which to reevaluate their prejudices about these workers, and so the prejudice is perpetuated. However, when a firm receives a tax credit for hiring a TJTC-eligible, it learns which of its employees are in TJTC target groups. As a result it gains an empirical basis for revising its opinions about target group members. When employers were asked to compare a specific TJTCeligible they hired to others hired for the same job, the TJTC-eligibles were reported to be just as productive and often more so. This suggests that among those who use the program, prejudices against TJTC-eligibles should diminish over time. While repeated measures of prejudice are not available to test this hypothesis, we do have repeated measures of TJTC use. The 1982 employer survey also contains data on the success of a TJTC-eligible who was hired in 1980 or early 1981. The impact that success (or lack of success) with a previous TJTC-eligible has on later use of the program can therefore be examined.

This was done by reestimating the models in Table 1 with additional variables representing past use of TJTC and the success of past use of subsidy programs. The model predicting TJTC certification after September 1981 contains three additional variables: an indicator variable for TJTC participation in 1980, an indicator variable for TJTC participation in the first nine months of 1981, and a continuous variable measuring the relative productivity of a subsidized worker who was hired in 1980 or the first nine months of 1981. The model predicting TJTC hiring between December and September 1981 contains two additional variables: an indicator variable for TJTC participation in 1980 , and a continuous variable measuring the relative productivity of a TJTC-eligible hired in 1980 or the first three months of 1981.

The coefficients on the reestimated models are presented in Table 2. Not surprisingly, participation in TJTC at one point in time is associated with greater TJTC hiring in later time periods. Having participated in 1980 quadrupled TJTC certifications in 1981 and doubled it in 1982. Certifying one or more TJTC-eligibles in the first nine months of 1981 multiplies expected TJTC certifications after September 1981 by six. The coefficients on favorable past experience are positive as hypothesized and, in 1982 are statistically significant. The coefficient implies a modest response to TJTC use to successful past experience with a subsidized employee. ${ }^{3}$ Bishop [1985] found that TJTC-

\footnotetext{
${ }^{3}$ The relative productivity of the subsidized employee is the difference in reported productivity during the third through twelfth week between a specific randomly selected subsidized new hire and the typical new hire for that job. The scale on which productivity was reported ranged from zero for absolutely no productivity to 100 for the highest productivity ever achieved by a worker in the same job. CETA/JTPA-
} 
eligibles in the retail and service sector were reported by their supervisor to be an average of 9 percent more productive in the third through twelfth week than unsubsidized workers doing the same job. A 9 percent productivity advantage by an early TJTC hire is predicted by the equation to increase TJTC hiring by 29 percent in 1981 and 18 percent in 1982.

\section{SUMMARY AND CONCLUSIONS}

In fiscal year 1985 the ratio of TJTC-certified new hires to total private sector employment was only about 0.7 percent, while unemployment was averaging 7 percent. Since many more people are unemployed at some point during the year than are unemployed at a particular point in time, it is clear that, relative to the problem it is addressing, TJTC is of quite modest scale. At such a scale, the program clearly cannot end welfare dependency and structural unemployment. Limitations on eligibility and small budgets do not account for the program's modest scale, for it is an entitlement and the pool of potential eligibles is quite large. The low rates of participation in TJTC by firms that hire unskilled workers appear to be a consequence of the high nonpecuniary costs of participation. Models predicting which establishments choose to participate in TJTC offer considerable support for this view. The primary source of the high participation costs appears to be the complicated eligibility rules, which make it difficult to identify and to recruit eligible disadvantaged workers, and the stigma attached to being a member of TJTC's target groups.

These problems are not easily solved, because they are inherent in a targeted employment subsidy. The very rationale of the program involves targeting hard-toemploy workers. Targeting, however, means that eligibility certification must be done by government agencies, and that employers are likely to perceive those eligible for subsidy as less productive than other job applicants. Both factors reduce participation. If less stigmatizing criteria were used to define target groups, eligibility would have to be broadened and the program's cost-effectiveness would be reduced.

The nonpecuniary cost of active participation-consciously trying to recruit and hire additional disadvantaged workers-appears to be particularly high. This suggests that much of the participation that does occur is probably passive and thus does not contribute to the social goal of increasing job opportunities for the disadvantaged. Stigma is clearly an important reason why employers perceive the costs of active participation to be so high. Most employers say they have no plans to ask the employment service for referrals of TJTC-eligibles when they "need to hire unskilled workers" in the future. When asked to explain why, employers cited the anticipated low quality or inappropriate skills of the people they expected would be referred. Together with the fact that the great majority of employers report that they screen for TJTC eligibility after making the hiring selection,

OJT workers were included among the subsidized workers because it was thought that positive (or negative) experiences with either program would color opinions of the other program. The mean of the productivity variable is 67 . If we randomly select two of a firm's new hires for a particular position, the typical magnitude of the difference between the productivity of these two workers is 15 points. The favorable past experience variable is based on the experience with only one of possibly many TJTC hires, it is probably measured with a good deal of error. This should bias coefficients toward zero, so the long-run impact of making successful placements of disadvantaged workers on future willingness to participate in TJTC is probably greater than that suggested by the results just reported. 
Table 2. Determinants of participation and impact of outreach and previous use (Number of observations $=2,621$ ).

\begin{tabular}{|c|c|c|c|c|c|c|}
\hline Variables & 198 & & 198 & & 19 & \\
\hline Indicators of the numb & of eligib & & & & & \\
\hline $\begin{array}{l}\text { Log estab. empl } \\
\text { in } 1980\end{array}$ & $0.761^{c}$ & $(26.9)$ & $0.792^{c}$ & $(29.9)$ & $0.283^{c}$ & $(7.92)$ \\
\hline $\begin{array}{l}\text { New hire rate in } \\
1979 \text { IV }\end{array}$ & $1.101^{\mathrm{c}}$ & (3.10) & $3.525^{\mathrm{c}}$ & $(12.4)$ & $3.105^{c}$ & $(9.20)$ \\
\hline $\begin{array}{l}\text { Proportion under } 25 \\
\text { in } 1978\end{array}$ & -0.125 & $(.65)$ & $0.937^{c}$ & $(5.86)$ & 0.330 & $(1.56)$ \\
\hline $\begin{array}{l}\text { Proportion unskilled } \\
\text { in } 1979\end{array}$ & $0.266^{b}$ & $(2.17)$ & $-0.204^{\mathrm{a}}$ & $(1.81)$ & $1.608^{c}$ & $(9.74)$ \\
\hline $\begin{array}{l}\text { Indicators of increment } \\
\text { Log index of general } \\
\text { training }\end{array}$ & 1 particip & $\frac{\text { ation cost }}{(7.49)}$ & $0.186^{\mathrm{c}}$ & $(5.36)$ & $-0.174^{c}$ & $(3.40)$ \\
\hline $\begin{array}{l}\text { Log index of specific } \\
\text { training }\end{array}$ & $-0.130^{\mathrm{a}}$ & $(1.79)$ & $-0.342^{c}$ & $(5.40)$ & -0.012 & $(.14)$ \\
\hline Unionized & $-0.271^{b}$ & $(2.37)$ & $0.466^{c}$ & $(4.49)$ & $-0.806^{c}$ & $(4.62)$ \\
\hline Proportion part-time & -0.237 & $(1.28)$ & $-0.509^{c}$ & (3.07) & 0.362 & $(2.02)$ \\
\hline Log cost of machine & $-0.075^{c}$ & $(3.86)$ & $-0.093^{c}$ & $(4.87)$ & $0.230^{c}$ & $(8.41)$ \\
\hline Wage residual & $-0.347^{c}$ & (3.57) & $0.254^{\mathrm{c}}$ & $(2.61)$ & $0.387^{\mathrm{c}}$ & $(2.70)$ \\
\hline Someone fired in 1979 & $0.144^{a}$ & $(1.83)$ & $0.242^{c}$ & $(3.15)$ & $-0.594^{c}$ & $(5.34)$ \\
\hline $\begin{array}{l}\text { Layoff based on } \\
\text { seniority } \\
\text { Indicators of fixed cost }\end{array}$ & 0.111 & $(.98)$ & 0.112 & $(1.02)$ & $0.331^{b}$ & $(2.20)$ \\
\hline $\begin{array}{l}\text { Log firm/estab. } \\
\text { employment }\end{array}$ & $-0.071^{b}$ & $(2.08)$ & 0.011 & $(.41)$ & $0.254^{c}$ & (7.70) \\
\hline $\begin{array}{l}\text { Has personnel office } \\
\text { Member of }\end{array}$ & -0.120 & $(1.43)$ & $0.140^{\mathrm{a}}$ & $(1.68)$ & 0.106 & $(.82)$ \\
\hline $\begin{array}{l}\text { local business } \\
\text { organization }\end{array}$ & $0.310^{c}$ & $(4.17)$ & -0.061 & $(.92)$ & $0.260^{c}$ & $(2.73)$ \\
\hline $\begin{array}{l}\text { Listed opening with } \\
\text { employment service } \\
\text { in } 1979\end{array}$ & $-0.503^{c}$ & $(6.92)$ & $-0.297^{c}$ & $(4.32)$ & $0.475^{c}$ & (4.47) \\
\hline Outreach & & & & & & \\
\hline $\begin{array}{l}\text { Government offer of } \\
\text { eligibility referral } \\
\text { Conversation about }\end{array}$ & $2.467^{c}$ & $(20.9)$ & $1.646^{\mathrm{c}}$ & $(18.9)$ & $1.914^{\mathrm{c}}$ & $(14.8)$ \\
\hline $\begin{array}{l}\text { TJTC not initiated } \\
\text { by firm }\end{array}$ & $0.626^{c}$ & $(3.74)$ & $0.444^{c}$ & $(3.77)$ & 0.167 & $(.87)$ \\
\hline $\begin{array}{l}\text { Both a conversation } \\
\text { and a referral offer } \\
\text { Previous receipt of subs }\end{array}$ & $\begin{array}{l}-0.937^{c} \\
\text { dies }\end{array}$ & $(5.18)$ & $-1.400^{c}$ & $(9.94)$ & $-1.160^{c}$ & $(5.22)$ \\
\hline New jobs tax credit & $\overline{0} .376^{\mathrm{c}}$ & $(4.31)$ & 0.093 & $(1.09)$ & $0.946^{\mathrm{c}}$ & $(8.67)$ \\
\hline $\begin{array}{l}\text { WIN in } 1977,78 \text {, } \\
\text { or } 79\end{array}$ & 0.122 & $(1.04)$ & $-0.188^{a}$ & $(1.7$ & 0.0 & (- \\
\hline CETA-OJT in 78 or 79 & $0.614^{c}$ & $(6.23)$ & $0.757^{b}$ & (8.77) & $0.981^{\mathrm{c}}$ & (7.75) \\
\hline $\begin{array}{l}\text { Participated in } \\
\text { TJTC in } 1980\end{array}$ & & & $1.307^{\mathrm{c}}$ & $(18.3)$ & $0.829^{c}$ & $(7.15)$ \\
\hline $\begin{array}{l}\text { Participated in } \\
\text { TJTC in } 1981\end{array}$ & & & & & $1.777^{\mathrm{c}}$ & $(14.0)$ \\
\hline $\begin{array}{l}\text { Favorable past } \\
\text { experience (TJTC } \\
\text { was better (+) or } \\
\text { worse }(-) \text { than } \\
\text { average) }\end{array}$ & & & 0.042 & $(1.49)$ & $0.028^{\mathrm{c}}$ & $(2.85)$ \\
\hline
\end{tabular}

$\mathrm{t}$-value in parenthesis.

a Significant at the $10 \%$ level (two sided).

${ }^{b}$ Significant at the $5 \%$ level (two sided).

c Significant at the $1 \%$ level (two sided). 
these findings suggest that windfalls are substantial and that unless costs per certified worker are extremely low, TJTC is not very cost effective.

Does the program do better from a more dynamic perspective? If, as we speculated earlier, TJTC is inducing employers to upgrade their opinions of the productivity of workers from targeted groups, the great cost of the pro-gram could be justified. No direct tests of this hypothesis were feasible in our data, but an indirect testwhether positive experience with a subsidized worker increases future use of TJTC-did yield results consistent with the hypothesis. More evidence is needed on this issue.

Despite this possibility, it would appear desirable to reform TJTC to reduce windfalls and increase cost-effectiveness. One simple but effective reform would be to make TJTC a marginal tax credit. To receive a tax credit in 1991, a firm would have to exceed the number of certifications it obtained in 1990, and only the excess of claims made in 1991 over claims made in 1990 would generate a tax credit. The cost of the program would decline, but the incentive to increase TJTC hiring would remain. The 1989 tax credit claims would also serve as the threshold in later years. It should not be updated yearly to reflect the firm's most recent use of the program, because an updating rule substantially reduces incentive effects and invites strategic behavior that consciously lowers the hiring of targeted labor in one year to enhance subsidy eligibility in later years [Bishop and Wilson, 1982].

Another and probably preferable alternative would be to drop the employer subsidy approach altogether and subsidize instead the wages of unemployed, disadvantaged individuals who find and keep a job [Lerman, 1982]. The employer would not know which (if any) employees were being subsidized, so the stigma would not affect employer response to the program. Two randomized experiments using this approach have found that offering job seekers a very modest reward for finding and keeping a job has substantial short- and medium-term effects on employment and earnings [RiveraCasale, Friedman, and Lerman, 1982; Spiegelman and Woodbury, 1987]. There is no subsidy scheme that does not generate windfalls for someone. Probably the most important difference between a wage supplement and an employment subsidy is who receives the windfalls. In an employment subsidy, the employers of low-wage workers receive the windfalls; in a wage rate supplement, low-wage disadvantaged workers receive them. They get nothing if they do not work. The windfall arises when individuals who would have worked in any case, without the wage supplement, get higher take-home pay as a result of the supplement.

On the more general issue of policy analysis, our conclusion is that the magnitude and structure of participation costs are critical to both the scale and effectiveness of tax subsidies and grant programs designed to change the behavior of firms and individuals. A policy analysis involving a simulation of response based on standard income and substitution parameters of production and utility theory can be very misleading. Policy analysis needs to incorporate the administrative and information costs (those costs involved in running and participating in the program) into the models used to simulate the cost and impact of tax subsidies and grant programs.

\section{APPENDIX: THE POISSON SPECIFICATION}


The first derivative of the likelihood is given by

$$
\partial L / \partial B=\sum_{\mathrm{i}=1}^{N}\left(-X_{i} \exp \left(X_{i} B\right)+N_{i} X_{i}\right)
$$

and the Hessian is

$$
\partial^{2} L / \partial B a^{\prime}=-\sum_{i=1}^{N} \mathrm{X}_{\mathrm{i}} \mathrm{X}_{\mathrm{i}}{ }_{\mathrm{i}} \exp \left(\mathrm{X}_{\mathrm{i}} \mathrm{B}\right) .
$$

The $\log$ likelihood is globally concave in $B$ and so standard nonlinear maximization routines yield the MLE of $B$. Under the Poisson specification, the expected value of the variance is given by $m_{i}$. Therefore, a unit increase in the explanatory variable will influence both the expected values and the variance of the outcomes. So $b_{j}$ represents relative increase in the mean and the variance of the outcome in response to the unit change in the right hand side variable $X_{i j}$.

Another measure of the impact of the change in firm characteristics is the change in the probability of participation. In particular, since 90 percent of the firms do not hire any TJTC workers, it is useful to obtain the change in the probability of hiring TJTCeligibles. The change in probability is obtained by differentiating the probability of not hiring any TJTC worker $(\operatorname{Pr}(0))$ by $X$ and then taking its negative value. The formula is given by the following:

$$
\frac{\partial \operatorname{Pr}(\text { Participation })}{\partial X_{i j}}=\operatorname{Pr}(0) m_{i} b_{j}=\Delta P_{i} b_{j}
$$

where $\Delta P_{i}=\operatorname{Pr}(0) m_{i}=m_{i} / \exp \left(m_{i}\right)$

Since $\Delta P_{i}$ is a function of $m_{i}$ only, for each value of the probability of no participation, the corresponding value of $\Delta P_{i}$ can be obtained. The next table shows the values of $\Delta P_{i}$ corresponding to various levels of $\operatorname{Pr}(0)$ :

$$
\operatorname{Pr}\left(\text { no participation) } \quad \Delta P_{i}\right.
$$

\begin{tabular}{|c|c|}
\hline 0.95 & 0.049 \\
\hline 0.90 & 0.095 \\
\hline 0.80 & 0.179 \\
\hline 0.70 & 0.250 \\
\hline 0.60 & 0.306 \\
\hline 0.50 & 0.347 \\
\hline & \\
\hline
\end{tabular}

The marginal effect of the ${ }_{j}$ th characteristic on the probability of participation is obtained by multiplying $\Delta P_{i}$ by $b_{i}$. 
The research reported here was supported by funds from Contract No. 99-4-576-77-091-01 of the Employment and Training Administration, U.S. Department of Labor. This paper has benefited from comments from Robert Lerman, Robert Hutchins, and staff at the Department of Labor. The opinions and conclusions expressed herein are solely those of the authors and should not be construed as representing the opinions or policies of any agency of the United States Government.

JOHN H. BISHOP is Associate Professor, School of Industrial and Labor Relations, Cornell University.

SUK KANG is Associate Professor, Tokyo Metropolitan University.

\section{REFERENCES}

Ashenfelter, Orley (1978), "Evaluating the Effects of the Employment Tax Credit," Conference Report on Evaluating the 1977 Economic Stimulus Package, U.S. Department of Labor, Office of the Assistant Secretary for Policy, Evaluation and Research.

Ashenfelter, Orley (1983), "Determining Participation in Income-Tested Social Programs," Journal of the American Statistical Association 78 (September), pp. 517525.

Bassi, Laurie J. (1986), "Evaluating Alternative Job Creation Strategies," Economic Inquiry 23 (October), pp. 671-690.

Bishop, John (1982), "Modeling the Decision to Apply for Welfare," in Irwin Garfinkel (ed.), Income Tested Transfer Programs: The Case For and Against (New York: Aca-demic Press).

Bishop, John (ed.) (1985), Targeted Jobs Tax Credit: Findings from Employer Surveys. (Columbus, OH: National Center for Research in Vocational Education, Ohio State University).

Bishop, John and Robert Lerman, (1977), "Wage Subsidies for Income Maintenance and Job Creation," in Robert Taggert (ed.), Job Creation: What Works (Salt Lake City, UT: Olympus Publication).

Bishop, John and Robert Haveman, (1979), "Targeted Employment Subsidies: Issues of Structure and Design," Creating Job Opportunities in the Private Sector, Washing-ton, D.C.: National Commission for Manpower Policy).

Bishop, John and Kevin Hollenbeck (eds.) (1986), The Effects of TJTC on Employers (Columbus, OH: National Center for Research in Vocational Education, Ohio State University).

Bishop, John H. and Mark Montgomery (1987), "Evidence on the Impact of the Targeted Jobs Tax Credit on the Level and Composition of Firm Employment." (Ithaca, NY: Center for Advanced Human Resource Studies, Cornell University).

Bishop, John and Charles Wilson (1982), "Effects on Firm Behavior," in R. H. Haveman and J. L. Palmer (eds.), Jobs for Disadvantaged Workers: The Economics of Employment Subsidies (Washington, D.C.: The Brookings Institution).

Burtless, Gary (1985), "Are Targeted Wage Subsidies Harmful? Evidence from a Wage Voucher Experiment," Industrial and Labor Relations Review 39(1), pp. 105-114. 
Christensen, Sandra (1984), The Targeted Jobs Tax Credit. Staff Memorandum.Prepared at the request of the Committee on Ways and Means of the U.S. House of Representatives for use of Congressional Staff members (Washington, D.C.: Congressional Budget Office).

Hall, Robert and Dale Jorgenson (1967), "Tax Policy and Investment," American Economic Review (June), pp. 391-414.

Hammermesh, Daniel S. (1978), "Subsidies for Jobs in the Private Sector," in John L. Palmer (ed.), Creating Jobs (Washington, D.C.: The Brookings Institution).

Hammermesh, Daniel S. and James Grant (1979), "Econometric Studies of Labor - Labor Substitution and Their Policy Implications," Journal of Human Resources 14 (Fall), pp. 518-541.

Hausman, Jerry, Bronwyn Hall, and Zvi Griliches (1984), "Econometric Models for Count Data with an Application to the Patents-R\&D Relationship," Econometrica 52(4), pp. 909-938.

Hollenbeck, Kevin (1986), "Employer Experience with TJTC: Results from Case Studies," in John Bishop and Kevin Hollenbck (eds.), The Effects of TJTC on Employers (Columbus, OH: National Center for Research in Vocational Education, Ohio State University).

Lerman, Robert (1982), "A Comparison of Employer and Worker Wage Subsidies," in R. H. Haveman and J. L. Palmer (eds.), Jobs for Disadvantaged Workers: The Economics of Employment Subsidies (Washington, D.C.: The Brookings Institution).

Moffitt, Robert (1983), "An Economic Model of Welfare Stigma," American Economic Review 73(5), pp. 1023-1035.

Montgomery, Mark (1982), "Individual Firm Response to Marginal Employment Subsidies." Unpublished PhD Dissertation. (Madison, WI: University of Wisconsin).

Moran, James, et al. (1982), "Jobs Tax Credit-The Report of the Wage Bill Subsidy Project, Phase II." (Madison, WI: Wisconsin Department of Health and Social Ser-vices).

Rivera-Casale, Cecilia, Barry Friedman, and Robert Lerman (1982), "Can Employer or Worker Subsidies Raise Youth Employment? An Evaluation of Two Financial Incentive Programs for Disadvantaged Youth" (Waltham, MA: Florence Heller Graduate School for Advanced Studies in Social Welfare, Brandeis University).

Schmid, Gunther (1981), "Public Finance Measures to Generate Employment for HardTo-Place People: Employer Wage Subsidies or Public Employment Programs," in Robert Haveman (ed.), Public Finance and Public Employment (Detroit, MI: Wayne State University Press).

Spiegelman, Robert and Stephen Woodbury (1987), The Illinois Unemployment Insurance Incentive Experiments. W. E. Upjohn Institute for Employment Research. Final report.

Ture, N. (1967), Accelerated Depreciation in the United States 1954-60. National Bureau of Economic Research (New York: Columbia University Press). 